\title{
FORMULASI STRATEGI DISTRIBUSI PRODUK SUSU BUBUK DI PT XYZ
}

\author{
FORMULATION OF THE DISTRIBUTION STRATEGY FOR MILK POWDER PRODUCT AT PT XYZ
}

\author{
Dwi Intan Widyastutie*), Sahara**), Kirbrandoko*) \\ *) Sekolah Bisnis, IPB University \\ Jl. Raya Padjajaran, Bogor 16151, Indonesia \\ **) Departemen Ilmu Ekonomi, Fakultas Ekonomi dan Manajemen, IPB University \\ Jl. Agatis Kampus IPB Dramaga, Bogor 16680, Indonesia
}

\begin{abstract}
Milk consumption in Indonesia is projected to increase by 4\% annually. Responding to current conditions, PT XYZ as a powder milk producer in Indonesia must be able to increase sales volume. Currently, PT XYZ has 9 sales distribution areas. This research aims to analyze distribution strategy of PT XYZ 1) Analyze the distribution performance of PT XYZ in each distribution area; 2) Analyze internal and external factor are influencing the sales of PT XYZ; 3) Formulated distribution strategy for increase sales in PT XYZ. The methods used at this study were portfolio analysis, Internal Factor Evaluation (IFE), External Factor Evaluation (EFE), SWOT and Quantitative Strategic Planning Matrix (QSPM). Based on portfolio analysis, regions were located in four quadrants (regional 1, III, IV and VI) were selected for further analysis. The four regions were analyzed by external and internal matrix, SWOT matrix and QSPM analysis. Then the best strategy was chosen in each region, regional I is to increase distribution density, the strategy chosen in regional III is to create a system related to product stock in branches. While in regional IV, namely increasing the availability of products in branches and in regional VI is strategy to increase the focus of distribution in medical branch (reduce return).
\end{abstract}

Keywords: Powder Milk, Distribution, IFE, EFE, SWOT, QSPM

\begin{abstract}
Abstrak: Konsumsi susu bubuk di Indonesia diproyeksikan meningkat 4\% pertahun. Menanggapi kondisi saat ini, PT XYZ sebagai produsen susu bubuk di Indonesia harus mampu meningkatkan volume penjualan. Saat ini, PT XYZ memiliki 9 wilayah distribusi penjualan. Penelitian ini bertujuan 1) menganalisis kinerja distribusi PT XYZ; 2) menganalisis faktor internal dan eksternal PT XYZ; 3) menyusun strategi distribusi PT XYZ untuk meningkatkan penjualan. Metode yang digunakan pada penelitian ini adalah analisa portofolio, Internal Factor Evaluation (IFE), External Factor Evaluation (EFE), SWOT dan Quantitative Strategic Planning Matrix (QSPM). Regional yang terletak di kuadran empat pada analisa portofolio (regional I, III, IV dan VI) dipilih untuk dilanjutkan analisa lebih lanjut. Empat regional tersebut dianalisa dengan analisa external internal matrix, SWOT matrix dan QSPM. Strategi terpilih pada masing-masing regional terhadap distribusi untuk mendukung penjualan pada setiap regional. Pada regional I ialah meningkatkan kerapatan distribusi, strategi terpilih pada regional III adalah membuat system terkait dengan stok produk di cabang. Sementara pada regional IV yaitu meningkatkan ketersediaan produk pada cabang dan pada regional VI adalah strategi Meningkatkan fokus distribusi pada cabang medis (mengurangi retur).
\end{abstract}

Kata kunci: Susu bubuk, distribusi, IFE, EFE, SWOT, QSPM

\footnotetext{
${ }^{1}$ Corresponding author:

Email: intanfasola@gmail.com
} 


\section{PENDAHULUAN}

Pertumbuhan ekonomi memiliki pengaruh penting sebagai indikator kemajuan suatu negara. Berdasarkan data Badan Pusat Statistik (BPS), ekonomi Indonesia mengalami peningkatan dari tahun sebelumnya menjadi 5,2\%, tetapi masih berada di bawah target pemerintah. Peningkatan pendapatan rata-rata tersebut diatas diikuti dengan peningkatan jumlah masyarakat kelas menengah. Peningkatan pendapatan masyarakat mengakibatkan pergeseran pola konsumsi pangan yang terjadi di masyarakat, salah satunya adalah peningkatan konsumsi susu di Indonesia.

Menurut Pusat Data dan Sistem Informasi Pertanian Sekretariat Jenderal Kementerian Pertanian 2016, perkembangan konsumsi susu di Indonesia di proyeksikan meningkat sebanyak $4 \%$ setiap tahun. Masyarakat Indonesia mengkonsumsi susu segar sekitar $18 \%$ dari total konsumsi susu, sementara $82 \%$ merupakan konsumsi susu bubuk (BPS, 2018). Di Indonesia, terdapat 10 perusahaan besar yang terdaftar sebagai pemain pada kategori produksi susu bubuk, salah satunya PT XYZ yang berada pada urutan ketiga berdasarkan survey data Nielsen 2019. Meningkatnya permintaan terhadap produk susu di Indonesia, maka permintaan terhadap produk susu juga akan meningkat. Sehingga diperlukan aspek manajemen strategi yang semakin kuat. Hutabarat (2006) mengatakan bahwa perusahaan dengan pernyataan visi yang terformalisasi mempunyai rata-rata return on share holder equity dua kali lebih tinggi dibandingkan dengan perusahaan yang mempunyai pernyataan visi yang tidak terformalisasi Menurut data Nielsen (2018), penjualan susu bubuk mengalami peningkatan baik secara volume dan value terhadap penjualan. Namun selama tiga tahun berturutturut, PT XYZ tidak mencapai target yang telah di tetapkan. Hal ini dikarenakan, hasil penjualan yang dilakukan oleh PT XYZ, tidak merata. Pada setiap daerah distribusi, tidak memenuhi target yang telah di tetapkan oleh PT XYZ. Dalam proses pendistribusian barang dan jasa dari tangan produsen ke tangan konsumen, diperlukan suatu metode atau strategi. Distribusi memiliki efek yang baik untuk profitabilitas, maka sebuah perusahaan harus memiliki rencana logistik yang baik serta rantai pasokan yang sangat baik pada manajemen distribusi (Singh, 2012).

Strategi distribusi yang selama ini digunakan oleh PT. XYZ ada dua, yaitu strategi distribusi intensif dan strategi distribusi selektif. Melalui pemilihan strategi saluran distribusi menjadi sebuah persoalan yang dihadapi oleh perusahaan. Strategi saluran distribusi dapat dilihat sebagai bagian khusus dari strategi pemasaran umum yang digunakan perusahaan untuk mencapai tujuan distribusinya (Karaxkha, 2015). PT XYZ melalui PT EPM, memiliki 9 regional yang terbagi-bagi dalam proses pendistribusian produk di seluruh wilayah Indonesia. Namun, terlihat pada grafik 1, sembilan regional yang telah ditetapkan menjadi titik pusat distribusi tidak mampu mencapai target penjualan yang telah ditetapkan oleh management.

Berdasarkan Gambar 1, pada ke sembilan saluran distribusi tidak memenuhi target penjualan yang sudah ditentukan oleh management. Diperlukan strategi yang tepat untuk meningkatkan target penjualan. Menurut Thompson, Strickland and Gamble (2010), tahapan proses pembuatan dan eksekusi strategi terdiri dari lima fase yaitu yang pertama adalah menentukan visi strategis, lalu yang kedua menentukan sasaran, tahap ketiga menentukan formulasi strategi untuk mencapai sasaran dan visi, dilanjutkan dengan implementasi dan eksekusi strategi dan yang terakhir adalah memonitor perkembangan dan mengevaluasi kinerja serta membuat perbaikan apabila timbul ketidaksesuaian maka dilakukan revisi.

Penjualan merupakan salah satu indikator paling terpenting dalam sebuah perusahaan. Perusahaan harus merumuskan tujuan saluran distribusinya menurut konsumen yang ditargetkan. Berdasarkan penelitian yang dilakukan oleh Musrifah dan Murwatiningsih (2017), orientasi pasar berpengaruh positif tetapi tidak signifikan pada kinerja pemasaran. Sementara orientasi kewirausahaan dan keunggulan bersaing berpengaruh positif dan signifikan pada kinerja pemasaran. Keunggulan bersaing dapat ditingkatkan melalui strategi saluran distribusi yang berdampak pada pencapaian tujuan distribusi di pasar sasaran. Mengembangkan strategi pemasaran campuran, produk, harga, promosi dan tempat merupakan bentuk hubungan antara pemenuhan target pasar dan pemasaran campuran. Pada penelitian ini, peneliti mengambil tiga faktor yang dapat memengaruhi penjualan susu bubuk pada masing-masing regional yaitu hubungan antara penjualan terhadap sumber daya manusia yang digunakan, terhadap jumlah outlet dan biaya promosi. Ketiga faktor ini akan di analisis dengan menggunakan analisis portofolio. Manajemen portofolio, pada dasarnya, tentang pengambilan keputusan untuk alokasi sumber daya, membuat pertukaran di seluruh 
bisnis, produk, dan proyek untuk mengalokasikan sumber daya mulai dari modal finansial ke pengetahuan organisasi (Koumou, 2019). Analisis portofolio adalah suatu analisis yang mengevaluasi suatu perusahaan, produk, atau pasar yang menggunakan faktor daya tarik pasar dan posisi bersaing sebagai indikator dalam mengenali jenis rencana strategis yang paling sesuai (Sudarjat, 2011). portofolio inovasi adalah serangkaian produk potensial di masa depan, sementara portofolio produk keduanya menginformasikan strategi inovasi dan memberikan masukan untuk masa depan upaya inovasi (Eggers dan Brasil, 2019).

Penelitian mengenai distribusi pada olahan pangan sudah dilakukan oleh Hastono (2019), untuk mengetahui pengaruh saluran distribusi terhadap kepuasan pelanggan pada PT Frisian Flag Indonesia. Diketahui banyaknya kendala pendistribusian produk kepada konsumen yang mengakibatkan pasokan produk tidak terealisasi dengan baik. Masalahmasalah tersebut yang mengakibatkan pasokan barang ke customer tidak terpenuhi dan berdampak ketidaklengkapan produk yang tersedia dikonsumen. Beberapa penelitian perencanaan strategi sebelumnya menggunakan metode portofolio sebagai penentu awal dalam menentukan alternatif strategi. Penelitian oleh Iskandar (2018), menggunakan analisis portofolio dengan matriks Grand Strategy, untuk menentukan strategi pengembangan bisnis yang dapat digunakan sebagai implikasi manajerial. Penelitian lain dilakukan oleh Sulistiyantoro (2005), menggunakan portofolio sebagai dasar menentukan alternative strategi untuk mengAnalisis strategi produk jasa telekomunikasi.
Setelah ditentukan 3 regional yang memiliki penjualan tertinggi, dilakukan Analisis internal dan eksternal terhadap ketiga regional tersebut. Analisis internal dilakukan dengan rantai nilai dan VRIO sehingga dapat diketahui lebih dalam mengenai proses dan kinerja distribusi yang telah dilakukan. Daya saing industri dalam meraih kinerja perdagangan internasional yang optimal salah satunya dipengaruhi oleh rantai nilai (value chain) yang efektif. (Nurimansyah, 2011). Rantai nilai yang efektif adalah kunci dari perusahaan memiliki keunggulan kompetitif yang dapat menghasilkan nilai tambah (Mangifera, 2015). Pada penelitian Gunawan dan Bernik (2013), analisis rantai nilai digunakan dengan tujuan untuk mengidentifikasi dimana keunggulan (advantage) atau kelemahan (disadvantage). Sementara untuk analisis eksternal dilakukan dengan analisis PEST yang lebih luas cakupannya untuk mengetahui kinerja distribusi dalam bisnis susu bubuk, baik ancaman dan peluang. Dengan mengenali dan mengevaluasi peluang dan ancaman eksternal, perusahaan akan mampu mengembangkan visi dan misi sebagai dasar strategi yang tepat untuk mencapai sasaran jangka panjang (Pudjadi, 2007). Analisis PEST menggunakan kerangka sederhana untuk mengkategorikan faktor lingkungan yang berkontribusi dalam menentukan posisi strategi suatu perusahaan (Keung, 2014). Berdasarkan latar belakang dan permasalahan yang ada tujuan dari penelitian ini adalah menganalisis faktor internal dan ektsernal dalam kinerja saluran distribusi apa saja yang memengaruhi penjualan susu bubuk di PT XYZ.

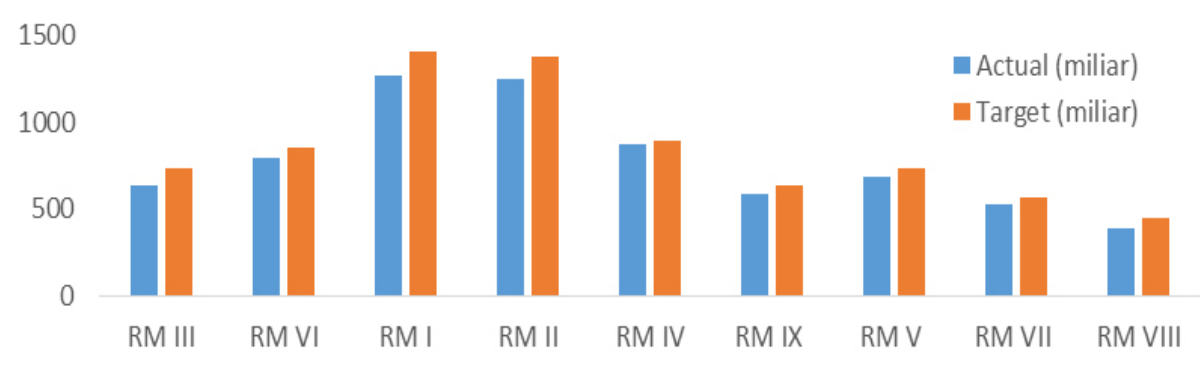

Gambar 1. Data penjualan PT XYZ berdasarkan saluran distribusi (miliar) 
Sementara untuk tujuan selanjutnya adalah menentukan strategi distribusi yang harus dilakukan oleh regional di PT XYZ dengan menggunakan matrix QSPM. QSPM yaitu matriks dirancang untuk menentukan daya tarik relatif dari berbagai tindakan alternatif. QSPM adalah alat yang memungkinkan para penyusun strategi mengevaluasi berbagai strategialternatif secara objektif, berdasarkan faktor-faktor keberhasilan penting internal dan eksternal yang diidentifikasi sebelumnya (Ginting, 2006). Teknik ini menentukan alternatif strategi terbaik secara objektif. QSPM menggunakan input dari analisis IFE, dan EFE serta analisis SWOT dan matriks IE (David, 2013). Selain itu, Saluran distribusi dapat dijadikan salah satu strategi yang menguntungkan untuk semua mitra. Pemilihan saluran distribusi merupakan hal yang sangat penting bagi seluruh perusahaan, dikarenakan efisiensi distribusi memiliki pengaruh yang penting pada kesuksesan operasional perusahaan. Pembatasan distribusi meliputi pemilihan indikator yang tepat, level dari pengukuran, penguraian efisiensi, tujuan yang bertentangan, sumber daya bersama (Kilibadra, 2016). SWOT dapat menunjukkan dengan tepat faktor-faktor dalam analisis. SWOT memungkinkan para analis untuk mengkategorikan faktor-faktor sebagai internal (kekuatan dan kelemahan) atau eksternal (peluang dan ancaman) (Yuksel, 2009). Penelitian sebelumnya juga dilakukan oleh Rachadian (2018) menggunakan matriks QSPM untuk menentukan strategi yang tepat dalma upaya merumuskan strategi yang tepat pembangkit listrik khusus wilayah Jakarta. Tujuan dari penelitian ini adalah menganalisis kinerja distribusi PT XYZ, menganalisis faktor internal dan eksternal PT XYZ dan menyusun strategi distribusi PT $\mathrm{XYZ}$ untuk meningkatkan penjualan

\section{METODE PENELITIAN}

Penelitian ini dilakukan di PT. XYZ yang terletak di Cakung, Jakarta Timur. Penelitian, pengolahan data, dan penulisan tesis akan dilaksanakan selama tiga bulan pada akhir April sampai Juli 2019. Metode penelitian yang digunakan adalah kualitatif deskriptif untuk mendapatkan gambaran informasi, penjelasan serta kondisi yang berkaitan dengan objek penelitian secara akurat, faktual dan sistematis mencakup kinerja masing-masing regional.

Data yang digunakan dalam penelitian ini adalah data primer dan data sekunder yang bersifat kualitatif dan kuantitatif. Data primer didapatkan melalui pengamatan langsung, sementara data sekunder didapatkan dari laporan akhir tahun management 3 tahun terakhir, data penjualan, kuisioner dari keenam pakar internal perusahaan serta studi literatur dan internet.

Teknik yang digunakan untuk mendapatkan informasi tersebut antara lain dengan observasi, dept interview dengan keenam pakar internal Manajer Distribusi cabang, Manajer Keuangan, Strategic Business Unit PT XYZ, Manajer produksi, Manager Business Development. Pemilihan pakar dilakukan secara sengaja (purpose sampling dengan judgment sampling) terdiri dari responden internal.

Berdasarkan latar belakang, rumusan permasalahan dan tujuan penelitian maka kerangka pemikiran yang dijadikan acuan yaitu penjualan pada sembilan regional distribusi tidak ada yang mencapai target dari management selama periode 3 tahun berturutturut, dengan angka rata-rata pencapaian pada $88 \%$. Oleh karena itu, diperlukan strategi alternatif yang dijalankan dan penentuan perencanaan strategi pada wilayah yang dijadikan prioritas wilayah yaitu dengan penjualan terbaik. Kerangka pemikiran dapat dilihat pada Gambar 2.

Penelitian ini dibagi menjadi beberapa tahapan, sesuai dengan tujuan penelitian. Tahapan pertama adalah analisis portofolio untuk mengetahui kondisi kinerja distribusi PT XYZ pada masing-masing wilayah distribusi, dilanjutkan dengan menganalisis lingkungan internal dan eksternal untuk mengkaji kinerja serta faktor kekuatan dan kelemahan distribusi pada PT XYZ. Selanjutnya menganalisis lingkungan eksternal makro dengan menggunakan analisis PEST untuk mengetahui tingkat persaingan bisnis PT XYZ dalam produk susu bubuk. Alat analisis yang digunakan adalah IFAS, EFAS dan SWOT. Hasil analisis ektsernal dan internal dijadikan bahan untuk analisis SWOT untuk merumuskan strategi PT XYZ yang dibutuhkan. Perumusan dilakukan dengan cara menggabungkan strategi yang ada pada faktor eksternal dan internal organisasi yang menjadi kunci dari isu strategi distribusi PT XYZ dengan cara penggabungan SO,ST,WO dan WT. Pemilihan strategi yang tepat diambil dengan analisis QSPM untuk menentukan strategi terbaik yang akan digunakan pada masing-masing wilayah prioritas distribusi PT XYZ. 


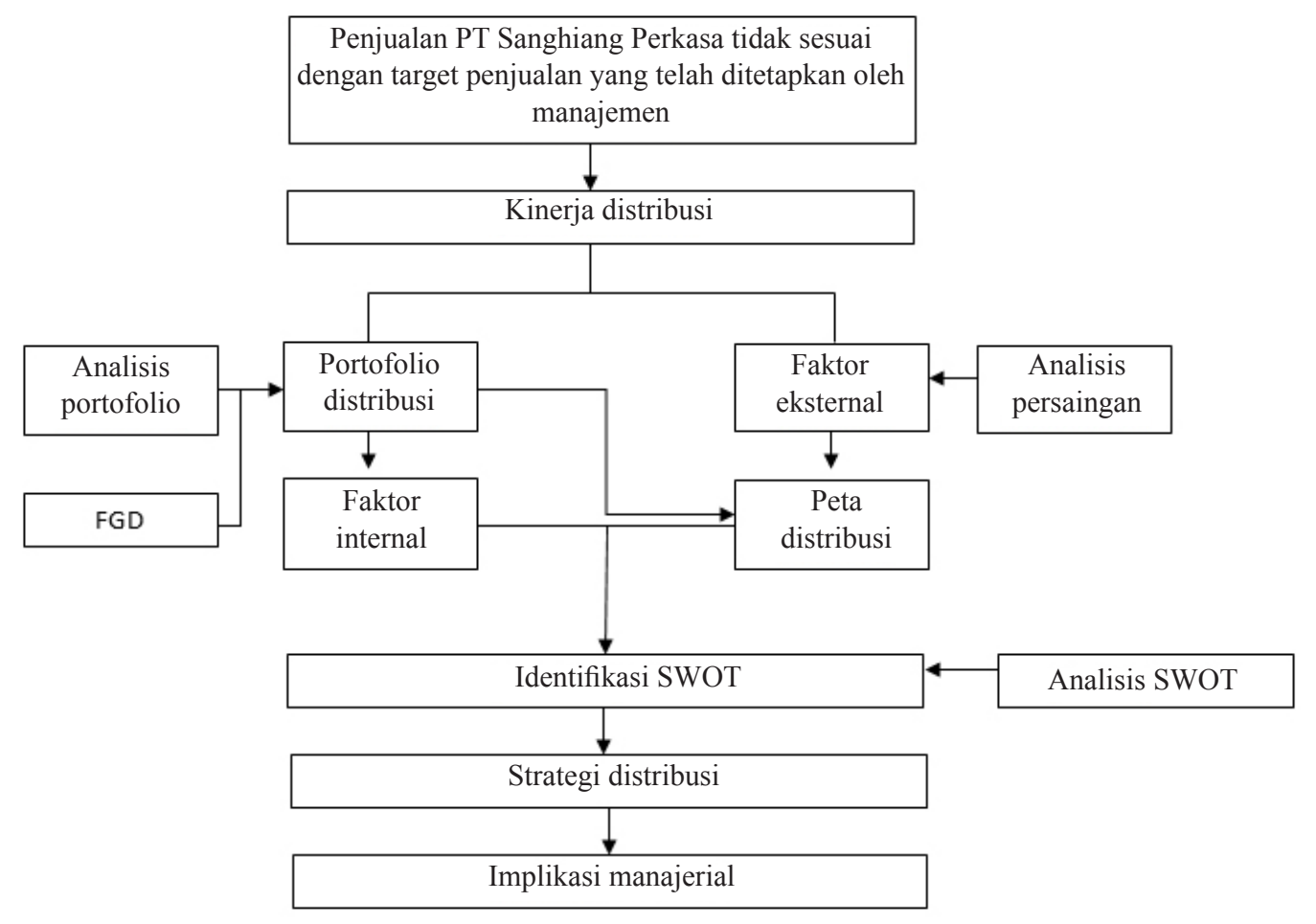

Gambar 2. Kerangka pemikiran penelitian

\section{HASIL}

\section{Gambaran Umum Perusahaan}

PT XYZ adalah sebuah perusahaan asal Indonesia yang bergerak dibidang nutrisi kesehatan. Berdiri sejak tahun 1982, produk nutrisi yang dihasilkan merupakan nutrisi kesehatan mulai sejak persiapan kehamilan, sampai nutrisi untuk manula. Sebagai salah satu perusahaan nutrisi ketiga terbesar di Indonesia, memiliki lebih dari 45 cabang di seluruh Indonesia dengan jumlah karyawan lebih dari 2.000 orang.

PT XYZ memiliki misi "We Provide Wellness to Millions". Sebuah pernyataan tegas yang menginspirasi PT XYZ untuk tumbuh, memastikan seluruh produknya dikembangkan dengan penuh tanggung jawab untuk membawa kebaikan hidup kepada lebih banyak orang, di Indonesia dan seluruh dunia. Misi ini pula yang telah membuat PT XYZ percaya bahwa perusahaan ini harus selalu memiliki sesuatu untuk semua orang dalam keluarga. Lini produk kesehatan dan nutrisi yang lengkap menjadi bukti kuat bahwa PT XYZ telah mencapai misi. Selain misi tersebut PT XYZ juga dibimbing oleh sebuah visi untuk membuat "PT XYZ Products in Every Home".

\section{Kinerja Saluran Distribusi}

Strategi distribusi yang selama ini digunakan oleh PT. XYZ ada dua, yaitu strategi distribusi intensif dan strategi distribusi selektif. Melalui PT EPM, PT XYZ memiliki 9 regional yang terbagi-bagi dalam proses pendistribusian produk XYZ di seluruh wilayah Indonesia yang dijelaskan pada Tabel 1. Kendalakendala yang selama ini dihadapi oleh PT. XYZ dalam melaksanakan strategi distribusi adalah kurangnya jaringan/mitra kerja dalam memasarkan produknya di daerah perifer, penyampaian barang ke konsumen akhir yang tidak tepat waktu, sulitnya memprediksi kebutuhan pasar akan produk yang dihasilkan, sulit untuk memonitoring saluran distribusi yang sedang berjalan di lapangan.

Sembilan regional tersebut diantaranya, regional I adalah Sumbagut (Medan, Pekan Baru, Batam, Aceh, Lhoksumawe, Pematang Siantar, Padang), regional II adalah Jatabek (Jakarta, Tangerang, Bekasi), regional III adalah Jabar (Bandung, Bogor, Sukabumi, Depok, Cirebon, Tasikmalaya), regional IV adalah Jatim (Surabaya, Jember, Kediri, Malang), regional V adalah Sulintim (Jayapura, Menado, Makassar, Palu), regional VI adalah Jateng (Semarang, Kudus, Solo, Purwokerto, Yogja, Tegal), regional VII adalah Sumbagsel (Lampung, Bengkulu, Palembang, Jambi, Pangkal 
Pinang), regional VIII adalah Bali Nustra (Denpasar, Mataram, Kupang) dan regional IX adalah Kalimantan (Banjarmasin, Balikpapan, Samarinda, Pontianak). Sembilan regional tersebut memiliki masing-masing perwakilan kantor pusat diantaranya Jakarta, Bandung, Semarang, Surabaya, Denpasar, Makassar, Balikpapan. Pada setiap regional tentunya memiliki target penjualan, biaya promosi, jumlah channel distribusi dan sumber daya manusia yang berbeda dan sudah di tetapkan oleh management pusat di PT XYZ.

Sembilan regional tersebut tidak mampu untuk mencapai target penjualan yang telah ditetapkan manajemen PT XYZ. Pencapaian rata-rata penjualan pada Sembilan regional di atas adalah $88 \%$. Pada tabel diatas, menunjukan tiga penjualan tertinggi diperoleh oleh regional I (Sumbagut), dilanjutkan dengan regional III (Jawa Barat) dan regional IV (Jawa Timur). Penjualan merupakan salah satu indikator paling terpenting dalam sebuah perusahaan. Pada penelitian ini, peneliti mengambil tiga faktor yang dapat memengaruhi penjualan susu bubuk di PT XYZ. Tiga faktor yang diambil adalah jumlah saluran penjualan pada tiap-tiap wilayah, biaya promosi yang diberikan pada masing-masing wilayah dan sumber daya manusia pada masing-masing wilayah regional. Sehingga diharapkan pada masing-masing faktor dapat terlihat wilayah mana yang memiliki penjualan yang baik dan di regional yang perlu melakukan pengembangan atau perhatian lebih.

Berdasarkan portofolio sales pada Gambar 2, posisi regional VIII (Balinustra), VII (Sumbagsel), V
(Sulintim), IX (Kalimantan) dan III (Jawa Barat) berada pada kuadran kedua, dengan kondisi terendah dalam penjualan dan jumlah saluran distribusi. Pada kuadran ke tiga dengan kondisi penjualan tinggi dan saluran distribusi terendah ditempati oleh regional II. Sementara pada kuadran 4, dengan kondisi penjualan tertinggi dengan jumlah distribusi terbanyak ditempati oleh regional I (Sumbagut) dan IV (Jatim) dan regional VI (Jateng).

Berdasarkan portofolio penjualan terhadap jumlah sumber daya manusia pada Gambar 3, regional V, III, VII dan VIII berada pada posisi terendah dalam penjualan dan sumber daya alam yang minim berada di kuadran dua, pada regional IX berada pada kategori penjualan rendah dengan sumber daya banyak yang cukup tinggi berada di kuadran satu. Kuadran empat, diisi oleh regional IV, III dan I dengan jumlah penjualan yang tinggi dan diikuti dengan jumlah sumber daya manusia yang banyak. Pada kuadran tiga diisi oleh regional VI.

Pada portofolio yang ketiga, yaitu penjualan dikaitkan dengan biaya promosi seperti yang terlihat pada Gambar 4. Posisi regional III, V, VII, VIII berada pada kuadran dua dengan biaya promosi yang rendah dan penjualan yang rendah. Sementara pada regional IX berada pada posisi biaya promosi tinggi dengan penjualan rendah, berada di kuadran satu. Pada kuadran empat, berada pada penjualan tinggi dan biaya promosi yang tinggi yaitu regional regional IV dan III. Pada kuadran tiga, berada pada regional I biaya promosi yang rendah dan penjualan yang tinggi.

Tabel 1. Penjualan Susu Bubuk PT Sanghiang Perkasa Tahun 2018-2019

\begin{tabular}{lcccccc}
\hline \multirow{2}{*}{ Regional Pemasaran } & \multicolumn{2}{c}{ Actual (miliar) } & \multicolumn{2}{c}{ Target (miliar) } & \multicolumn{3}{c}{ Pencapaian } \\
\cline { 2 - 7 } & 2018 & 2019 & 2018 & 2019 & 2018 & 2019 \\
\hline RM III (Jabar) & 629 & 639 & 696 & 738 & $87 \%$ & $90 \%$ \\
RM VI (Jateng) & 701 & 799 & 779 & 850 & $94 \%$ & $90 \%$ \\
RM I (Sumbagut) & 1200 & 1274 & 1396 & 1406 & $90 \%$ & $86 \%$ \\
RM II (Jatabek) & 1012 & 1254 & 1169 & 1381 & $90 \%$ & $87 \%$ \\
RM IV (Jatim) & 770 & 879 & 844 & 897 & $97 \%$ & $91 \%$ \\
RM IX (Kalimantan) & 531 & 591 & 649 & 640 & $87 \%$ & $82 \%$ \\
RM V (Sulintim) & 582 & 687 & 644 & 734 & $93 \%$ & $90 \%$ \\
RM VII (Sumbagsel) & 475 & 532 & 532 & 565 & $94 \%$ & $89 \%$ \\
RM VIII (Balinustra) & 390 & 392 & 464 & 450 & $87 \%$ & $84 \%$ \\
\hline
\end{tabular}




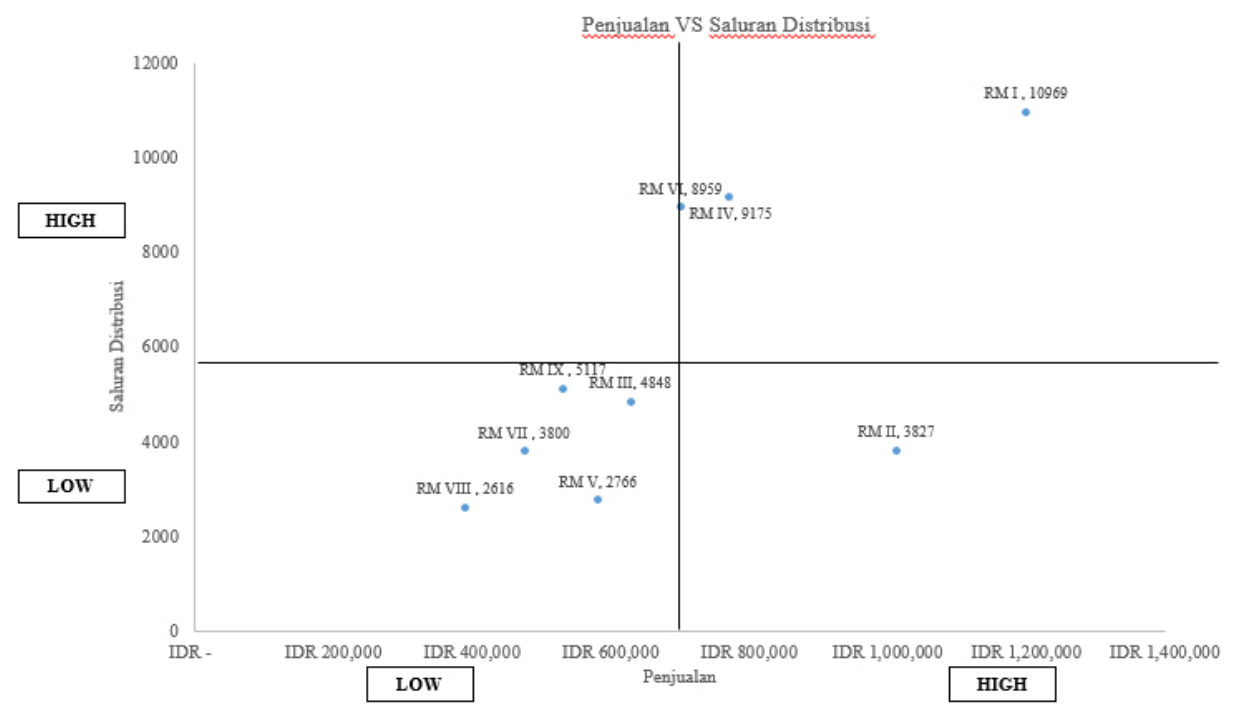

Gambar 2. Analisis porfolio penjualan vs saluran distribusi

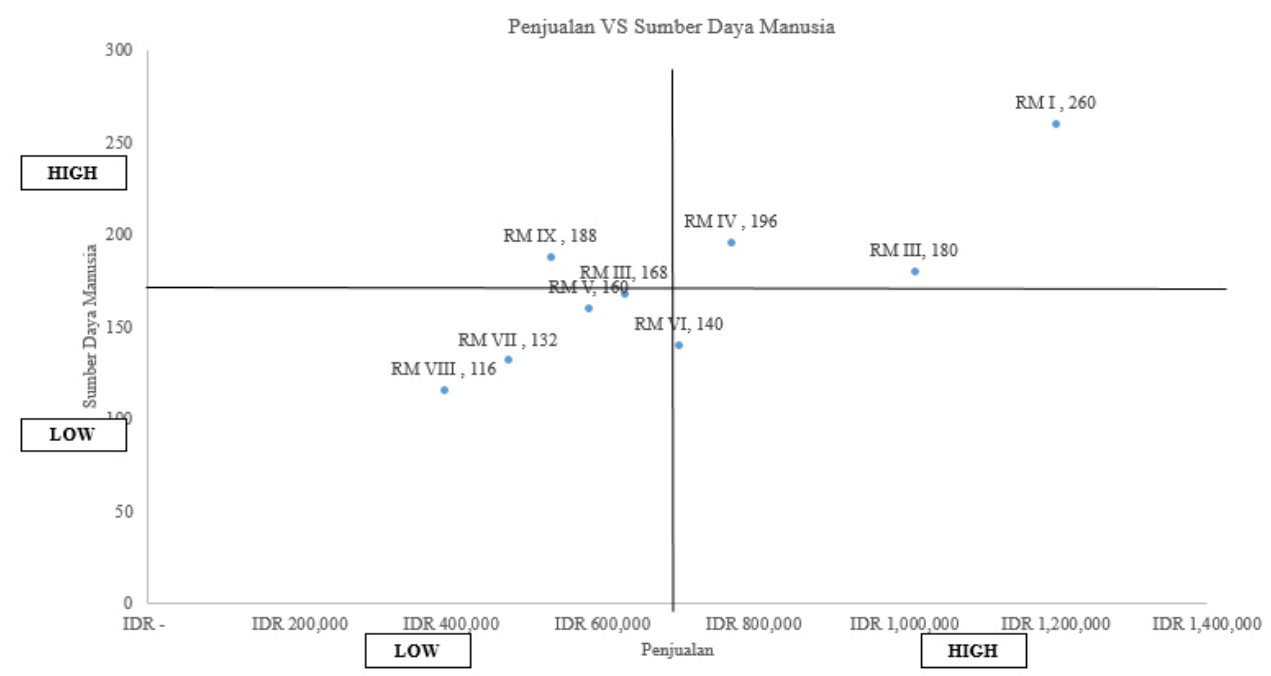

Gambar 3. Analisis porfolio penjualan vs sumber daya manusia

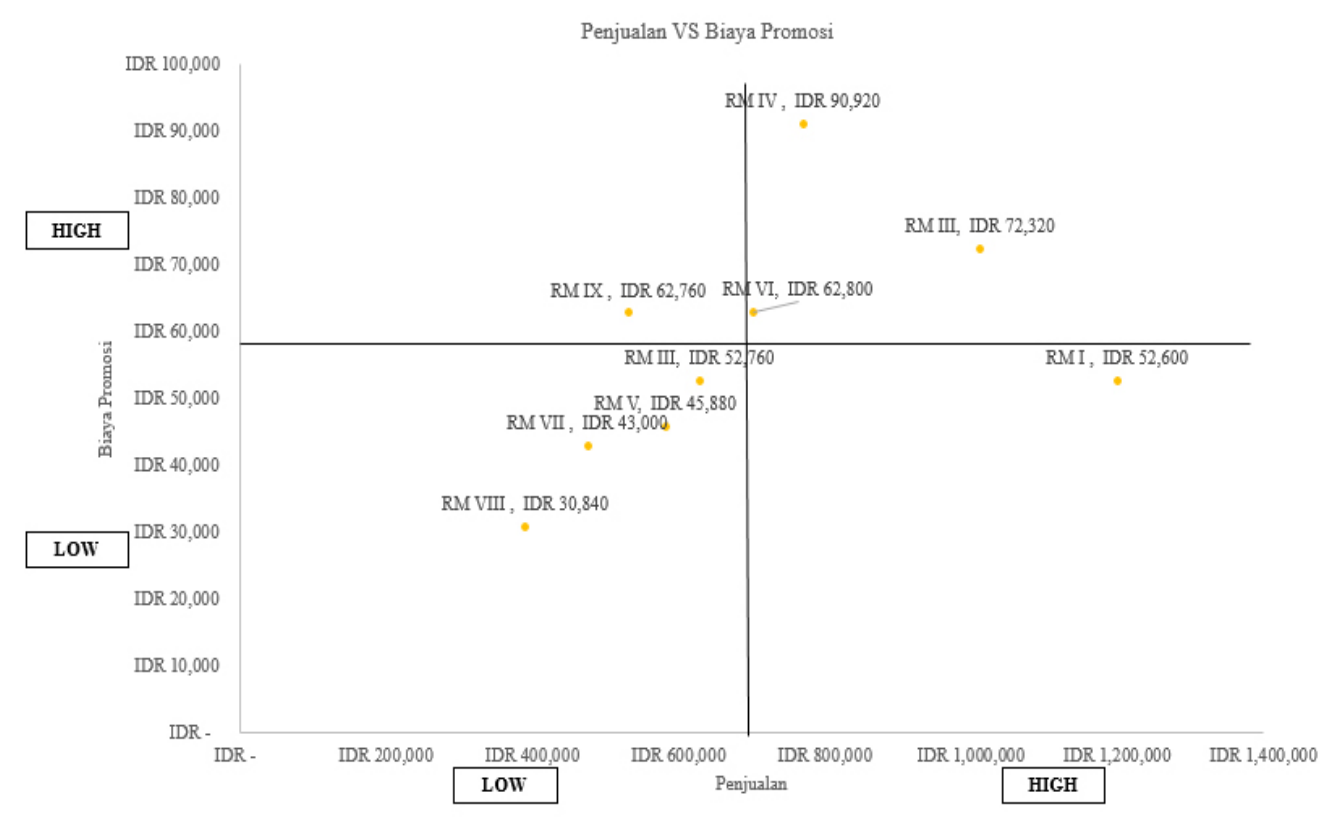

Gambar 4. Analisis porfolio penjualan vs biaya promosi 
Berdasarkan ketiga portofolio, penjualan tinggi sebanding dengan banyaknya saluran distribusi, penggunaan sumber daya manusia dan biaya promosi yang dikeluarkan oleh perusahaan. Apabila dilihat, pada masing-masing portofolio di kuadran empat, diisi oleh regional I (Sumbagut), regional IV (Jawa Timur), regional III (Jawa Barat) dan regional VI (Jawa Tengah).

\section{Identifikasi Faktor Internal dan Eksternal}

Identifikasi faktor internal dan eksternal merupakan langkah selanjutnya yang diambil dalam pembuatan strategi distribusi produk susu bubuk di PT XYZ. Dalam tahap ini dilakukan pencarian data dengan menggunakan analisis internal. Analisis internal bertujuan mencari kekuatan dan kelemahan dari PT XYZ dalam kondisi persaingan serta jalur distribusi. Pencarian faktor internal dilakukan dengan cara mewawancarai keenam responden pakar dengan alat bantu kuesioner dari internal perusahaan serta menganalisis dengan rantai nilai, untuk analisis eksternal didapat dari analisis PEST.

Hasil portofolio sebelumnya, berdasarkan arahan dari managemen peneliti akan memfokuskan pada 4 wilayah cabang distribusi yang berada pada kuadran keempat yaitu I (Sumbagut), regional IV (Jawa Timur), regional III (Jawa Barat) dan regional VI (Jawa Tengah) yang berada pada kuadran keempat. Pada regional I memiliki empat faktor internal, dan delapan faktor eksternal. Pada regional IV (Jawa Timur) memiliki 7 faktor eksternal dan delapan faktor internal. Pada regional III (Jawa Barat) memiliki tiga faktor eksternal dan empat faktor internal. Terakhir pada regional VI (Jawa Tengah) memiliki empat faktor eksternal dan tujuh faktor internal.

Berdasarkan Tabel 2 dan 3, analisis IFE menunjukan bahwa kekuatan utama regional I adalah mampu menjalin hubungan baik dengan outlet pareto, sehingga tidak ada kenaikan biaya yang signifikan. Sedangkan kelemahan utama yang dimiliki oleh regional I adalah jumlah produk yang sudah dibeli dikembalikan cukup tinggi dengan skor 0.20. Pada External Factor Evaluation dicari faktor peluang dan ancaman untuk PT XYZ. Hasil bobot didapatkan berdasarkan pengisian kuesioner pairwise comparison antara faktor internal maupun eksternal lain oleh keenam pakar. Dari keenam pakar tersebut, diambil nilai modus, yaitu angka yang sering muncul diantara pakar. Peluang utama untuk PT $\mathrm{XYZ}$ adalah jangkauan wilayah distribusi masih banyak dengan nilai tertimbang 0.714 sedangkan ancaman utama PT XYZ adalah banyaknya sub-distribusi yang pindah dengan skor 0.889 .

Tabel 2. Rekapitulasi Internal Faktor Analysis Summary (IFAS) Regional I

\begin{tabular}{lccc}
\hline Faktor Internal & Bobot & Rating & Skor \\
\hline $\begin{array}{l}\text { Faktor Kekuatan } \\
\text { Eksekusi Program di Modern Trade Independen dan Regional Key Account sudah } \\
\text { berjalan baik }\end{array}$ & 0,12 & 3 & 0,35 \\
$\begin{array}{l}\text { Memiliki hubungan yang baik dengan Pareto Outlet sehingga tidak ada kenaikan } \\
\text { biaya yang signifikan }\end{array}$ & 0,15 & 4 & 0,62 \\
$\begin{array}{l}\text { Hubungan dengan key person desicion maker distribusi dan Medis Pareto sudah } \\
\text { terjalin baik. }\end{array}$ & 0,15 & 4 & 0,58 \\
Faktor Kelemahan & & & \\
Pemenuhan purchase order Cab.Batam belum maksimal & 0,06 & 2 & 0,13 \\
Masih fokus pada Pareto & 0,16 & 1 & 0,16 \\
Quality control data masuk masih kurang detail & 0,14 & 1 & 0,14 \\
Pengembalian barang yang dibeli & 0,10 & 2 & 0,20 \\
Ratio Expense Tinggi & 0,12 & 1 & 0,12 \\
\hline
\end{tabular}


Berdasarkan Tabel 4 dan 5, kekuatan utama pada regional III adalah kerapatan distribusi yang baik dan dimiliki oleh regional III. Dan kelemahan yang dimiliki oleh regional III adalah lambatnya konsolidasi intern dalam pengambilan keputusan dengan skor 0.35. Meskipun memiliki kerapatan distribusi yang baik, jika tidak didukung dengan pengambilan keputusan yang cepat maka kekuatan tersebut tidak akan berjalan dengan baik. Sedangkan pada External Factor Evaluation untuk peluang PT XYZ pada regional III adalah trend belanja online semakin naik, sehingga e-commerce berkembang. Hal ini dapat menjadi peluang yang cukup potensial yang bisa di gunakan untuk meningkatkan volume penjualan pada regional III. Sedangkan ancaman utama PT XYZ pada regional III adalah Toko Pareto (SAT, Yogya) menerapkan managemen Gudang, sehingga mengurangi buffer stok toko skor 0.714 .
Berdasarkan Tabel 6 dan 7, PT XYZ untuk regional IV memiliki 3 kekuatan dan 5 kelemahan. Kekuatan utama pada PT XYZ pada regional IV adalah hubungan medis yang terjalin baik antara sumber daya manusia dengan wilayah medis terkait (Rumah Sakit, Rumah Bersalin dan lain-lain). Kelemahan yang dimiliki oleh PT XYZ regional IV adalah belum meratanya stokist dengan skor 0.48. Sementara untuk Analisis eksternal, peluang utama untuk PT XYZ adalah masih banyak peluang bisnis di medis (Emos). Hal ini dapat menjadi peluang yang cukup potensial yang bisa di gunakan untuk meningkatkan volume penjualan pada regional IV, mengingat reputasi PT XYZ yang sangat baik di konsumen dan bisa semakin meningkat jika melakukan kerjasama distribusi di area medis. Sementara untuk ancaman, yang dimiliki oleh regional IV yaitu sumber daya manusia yang kurang dengan skor 0.352 .

Tabel 3, Rekapitulasi External Faktor Analysis Summary (EFAS) Regional I

\begin{tabular}{lccc}
\hline Faktor Eksternal & Bobot & Rating & Skor \\
\hline Faktor Peluang & & & \\
Jangkauan wilayah distribusi masih banyak & 0,24 & 3 & 0,714 \\
Tidak hanya bisnis Transaksional & 0,11 & 1 & 0,111 \\
Outlet non Pareto Potensial & 0,17 & 2 & 0,349 \\
Faktor Ancaman & & & \\
Piutang Outlet & 0,14 & 3 & 0,429 \\
Banyaknya sub-distribusi yang pindah & 0,22 & 4 & 0,889 \\
Biaya tidak terduga dari rekanan & 0,11 & 2 & 0,222 \\
\hline
\end{tabular}

Tabel 4. Rekapitulasi Internal Faktor Analysis Summary (IFAS) Regional III

\begin{tabular}{lccc}
\hline Faktor Internal & Bobot & Rating & Skor \\
\hline Faktor Kekuatan & & & \\
Penjualan meningkat di berbagai store & 0,22 & 3 & 0,65 \\
Memiliki kerapatan distribusi yang baik & 0,26 & 3 & 0,78 \\
Faktor Kelemahan & & & \\
Distribusi produk tidak berjalan lancar, sering kali terjadi out of stock pada cabang & 0,30 & 1 & 0,30 \\
Lambatnya konsolidasi intern dalam pengambilan keputusan. & 0,17 & 2 & 0,35 \\
\hline
\end{tabular}

Tabel 5. Rekapitulasi External Faktor Analysis Summary (EFAS) Regional III

\begin{tabular}{lccc}
\hline Faktor Eksternal & Bobot & Rating & Skor \\
\hline Faktor Peluang & & & \\
Masih besarnya Potensi Outlet GT yang bisa di kelola, kontribusi GT baru 9\% & 0,29 & 3 & 0,8571 \\
$\begin{array}{l}\text { Trend belanja online semakin naik sehingga e-commerce berkembang } \\
\text { Faktor Ancaman }\end{array}$ & 0,36 & 3 & 1,0714 \\
$\begin{array}{l}\text { Toko Pareto (SAT, Yogya) menerapkan managemen Gudang, sehingga mengurangi } \\
\text { buffer stok toko }\end{array}$ & 0,36 & 2 & 0,714 \\
\hline
\end{tabular}


Pada Tabel 8 dijelaskan faktor kekuatan utama yang dimiliki oleh regional VI adalah program DBA yang cukup menarik sehingga dapat menambah titik potensial penjualan. Sementara kelemahan utama pada regional VI adalah ketersediaan produk yang masih sering kosong. Sementara itu, untuk Analisis matriks EFE, terdapat dua faktor peluang dan dua faktor ancaman pada regional VI (Tabel 9). Faktor peluang tertinggi pada regional VI adalah masih banyaknya peluang aktifitas di medis dan non medis yang masih belum dilakukan oleh competitor. Dan untuk faktor ancaman tertinggi dengan skor 0.56 yaitu keterbatasan budget promosi. Setelah matriks IFE dan EFE didapatkan, maka langkah selanjutnya peneliti akan membuat matriks SWOT. Menurut Wheelen dan David (2012). Matriks SWOT merupakan sebuah matriks yang digunakan untuk membuat strategi dari data-data yang ada. Berdasarkan data analisis IFAS dan EFAS dapat disusun analisis matrik SWOT untuk mengidentifikasi berbagai faktor dalam rangka merumuskan strategi perusahaan. Analisis SWOT dapat dilihat pada Gambar $5,6,7$, dan 8 .

Tabel 6. Rekapitulasi Internal Faktor Analysis Summary (IFAS) Regional IV

\begin{tabular}{|c|c|c|c|}
\hline Faktor Internal & Bobot & Rating & Skor \\
\hline \multicolumn{4}{|l|}{ Faktor Kekuatan } \\
\hline Man power lebih fokus & 0,02 & 3 & 0,05 \\
\hline Adanya hubungan baik dengan bidang medis (RS, RSB, BD, PKM) & 0,12 & 4 & 0,47 \\
\hline Man power yang produktif & 0,09 & 4 & 0,37 \\
\hline \multicolumn{4}{|l|}{ Faktor Kelemahan } \\
\hline Jangkauan MD yang terlalu luas & 0,11 & 2 & 0,22 \\
\hline Jalannya program yang belum lancar (Kalbe store) & 0,10 & 2 & 0,20 \\
\hline Aplikasi digital yg belum merata & 0,08 & 1 & 0,08 \\
\hline Koordinasi dengan subdist yang masih perlu ditingkatkan & 0,12 & 3 & 0,36 \\
\hline Belum meratanya Stokist & 0,16 & 3 & 0,48 \\
\hline
\end{tabular}

Tabel 7. Rekapitulasi External Faktor Analysis Summary (EFAS) Regional IV

\begin{tabular}{|c|c|c|c|}
\hline Faktor Eksternal & Bobot & Rating & Skor \\
\hline \multicolumn{4}{|l|}{ Faktor Peluang } \\
\hline Masih banyak peluang bisnis di medis (Emos) & 0,1 & 4 & 0,571 \\
\hline Masih banyak peluang bisnis di GT Retail dan Baby shop & 0,2 & 3 & 0,495 \\
\hline Banyaknya outlet GT baru & 0,1 & 2 & 0,286 \\
\hline \multicolumn{4}{|l|}{ Faktor Ancaman } \\
\hline Jumlah man power yang kurang & 0,2 & 2 & 0,352 \\
\hline Budget minim & 0,1 & 2 & 0,242 \\
\hline Adanya peraturan pemerintah & 0,1 & 2 & 0,242 \\
\hline Adanya peraturan NKA ( Min Max,TBAT) & 0,1 & 2 & 0,264 \\
\hline
\end{tabular}

Tabel 8. Rekapitulasi Internal Faktor Analysis Summary (IFAS) Regional VI

\begin{tabular}{lccc}
\hline Faktor Internal & Bobot & Rating & Skor \\
\hline Faktor Kekuatan & & & \\
Memiliki hubungan dengan bidan yang baik & 0,11 & 3 & 0,32 \\
Program DBA yang cukup menarik sehingga menambah titik creating demand & 0,16 & 4 & 0,66 \\
Faktor Kelemahan & & \\
Problem ketersediaan produk yang sering kosong di tahun 2018 & 0,21 & 1 & 0,21 \\
Problem Stokiist yang belum ada di setiap cabang & 0,16 & 1 & 0,16 \\
Dukungan transportasi untuk mengcover ke area yang jauh masih kurang dan & 0,09 & 2 & 0,19 \\
terbatas & & 0,09 & 2 \\
Berkurangnya man power yang mengcover channel GI & 0,16 & 1 \\
Return Produk & & 0,19 \\
\hline
\end{tabular}


Tabel 9. Rekapitulasi Eksternal Faktor Analysis Summary (EFAS) Regional VI

\begin{tabular}{|c|c|c|c|}
\hline Faktor Eksternal & Bobot & Rating & Skor \\
\hline \multicolumn{4}{|l|}{ Faktor Peluang } \\
\hline $\begin{array}{l}\text { Masih ada peluang untuk pengembangan outlet Medis baik dari activity maupun } \\
\text { kerjasama }\end{array}$ & 0,28 & 2 & 0,56 \\
\hline $\begin{array}{l}\text { Masih Banyaknya peluang Activity di Medis \& Non Medis (klinik,pabrik,koperasi) } \\
\text { yang belum dilakukan oleh competitor }\end{array}$ & 0,24 & 3 & 0,72 \\
\hline \multicolumn{4}{|l|}{ Faktor Ancaman } \\
\hline $\begin{array}{l}\text { Adanya Regulasi Pemerintah /IBI/Dinkes terkait penggunaan susu hamil \& } \\
\text { menyusui di beberapa daerah yang secara tegas melarang melakukan kegiatan yang } \\
\text { berhubungan dengan promosi }\end{array}$ & 0,2 & 2 & 0,4 \\
\hline Keterbatasan budget promosi & 0,28 & 2 & 0,56 \\
\hline
\end{tabular}

\begin{tabular}{|c|c|c|}
\hline & Kelauatan (S) & Kelemahan (W) \\
\hline & 1. ElcsekusiProgram diModern Trade & \\
\hline & Independen dan RegionalK ey Account svdah & 1. Pemervhan purchase order $\mathrm{C}$ ab. Batam \\
\hline & berjalanbaik & behmmaksimal \\
\hline Matrilcs S WOT & 2. Memiliki huburgan yarg baik dengan Pareto & 2. Retux tinggi \\
\hline Regional I & $\begin{array}{l}\text { Ovtlet sehirgga tidak ada kenzikan biaya yang } \\
\text { signifilan }\end{array}$ & $\begin{array}{l}\text { 3. Quality Control Data Masuk All masih } \\
\text { lavang }\end{array}$ \\
\hline & 3. Hubungan dengan key person desicion & 4. Masih fokus pad a Pareto \\
\hline & $\begin{array}{l}\text { maker distribusid an Med is Pareto svdah } \\
\text { terjalin baik. }\end{array}$ & 5. Ratio Expense Tinggi \\
\hline Pehang $(\mathrm{O})$ & Strategi (S-O) Offersive & Strategi (W-O) Korektif \\
\hline 1. Jargkanan wilayah distribusi & & 1. Meringlathan efisiers idurasi pengiriman \\
\hline masih banyak & 1. Pertuasan pangsa pasar & 2. Meringlatkan kompetensi SDM terkait \\
\hline $\begin{array}{l}\text { 2. Tidak hanya bisnis } \\
\text { Transaksional }\end{array}$ & 2. Meningkafican kerapatan distribusi & pengeloland data \\
\hline Ancaman (T) & Strategi(S-T) Diversificasi & Strategi(W-T) Difensif \\
\hline 1. Pivtang Outlet & 1. Memberikan kebijakan terb aru terkait dengat & \\
\hline 2. Banyalorya sub-distribusi yang & keterlanb atan penbayaran (limit laedif), serta & \\
\hline pind ah & follow up secara berkala & \\
\hline 3. Biaya bdak terduga dari & 2. Menjalin huburgan yarg baik kepada outlet & $\begin{array}{l}\text { 1. Ferancargan program Nelationsintp } \\
\text { Marketing }\end{array}$ \\
\hline & $\begin{array}{l}\text { 3. Mempertahankan keunggulan biaya melahi } \\
\text { efisiensi biaya distribusi }\end{array}$ & \\
\hline
\end{tabular}

Gambar 5. Matriks SWOT PT XYZ Regional I

\begin{tabular}{|c|c|c|}
\hline & Kekuatan (S) & Kelemahan (W) \\
\hline $\begin{array}{l}\text { Matrils SWOT } \\
\text { Regional IV } \\
\text { Jawa Timur }\end{array}$ & $\begin{array}{l}\text { 1. Manpower lebih fokus } \\
\text { 2. Adanya hubungan baik dengan } \\
\text { RS RSB,BD,PKM, Bidan, Ouflet } \\
\text { Distribusi } \\
\text { 3. Manpower yang produktif }\end{array}$ & $\begin{array}{l}\text { 1. J anghauan MD yang terlah has } \\
\text { 2. Jalannya program yang behm lancar } \\
\text { (Kalbe store) } \\
\text { 3. Aplikasi digital yg behm merata } \\
\text { 4. Koordinasi dengan subdist yang } \\
\text { masih perlv ditingkatkan } \\
\text { 5. Belummeratanya S tokist }\end{array}$ \\
\hline Pehrang (O) & Strategi (S - O) Offensive & S trategi (W-O) Korektif \\
\hline $\begin{array}{l}\text { 1. Masih banyak peluang bisnis di } \\
\text { medis (Emos) } \\
\text { 3. Masih banyak peluang bisnis di GT } \\
\text { Retail dan Baby shop } \\
\text { 4. Banyaknya cutlet GT baru }\end{array}$ & $\begin{array}{l}\text { 1. Menbuat lis toutlet baru untuk } \\
\text { dilakukan pembinaan dan brand ing } \\
\text { sehingga sejalan dengan demand yang } \\
\text { sudah terbentuk }\end{array}$ & $\begin{array}{l}\text { 1. Memas tikan pelayanan penjualan } \\
\text { dengan baik ses uai dengan permintaan } \\
\text { pada setiap subdist } \\
\text { 2. Fokcus meningkatkan jumlah cab ang } \\
\text { pada GT retail F okcus pad a penjualan di } \\
\text { minimarket dan supermarket } \\
\text { 4. Meninglatkan keterse diaan produk } \\
\text { pada cabang }\end{array}$ \\
\hline Ancaman $(T)$ & Strategi (S -T) Diversifilcasi & S trategi (W-T) Difensif \\
\hline $\begin{array}{l}\text { 1. Jumlah man power yang lavrang } \\
\text { 2. Budget minim } \\
\text { 3. Adanya peraturan pemerintah } \\
\text { 4. Adanya peraturan NKA ( Min }\end{array}$ & $\begin{array}{l}\text { 1. Meningkafkan kompetensi SDM } \\
\text { yang folas terhadap medis channel }\end{array}$ & $\begin{array}{l}\text { 1. Meninglatkan jumlah man power } \\
\text { pada masing-masing cab ang }\end{array}$ \\
\hline
\end{tabular}

Gambar 6. Matriks SWOT PT XYZ Regional IV 


\begin{tabular}{|c|c|c|}
\hline & Kekuatan (S) & Kelemahan (W) \\
\hline $\begin{array}{c}\text { RegionalIII } \\
\text { Bandung, Tasikma laya, Cirebon, } \\
\text { Depok, Bogor, Sukabumi }\end{array}$ & $\begin{array}{l}\text { 1. Perjua lan meningkat di berbagai } \\
\text { store } \\
\text { 2. Memiliki ketapatan distribusi yang } \\
\text { baik }\end{array}$ & $\begin{array}{l}\text { 1. Distribusi produk tidak berjalan } \\
\text { lancar, sering kali terjadi out of stock } \\
\text { pada cabang } \\
\text { 2. Lambatnya konsolidasi intem }\end{array}$ \\
\hline Peluang $(\mathrm{O})$ & Strategi $(\mathrm{S}-\mathrm{O})$ Offensive & Strategi (W-O) Korektif \\
\hline $\begin{array}{l}\text { 1. Mh sih besarnya Potensi Outlet GT } \\
\text { yang bisa di kelo h, kontribusi GT } \\
\text { baru } 9 \% \\
\text { 2. Trend be hanja online semakin naik } \\
\text { sehing ga e-commerce berkembang }\end{array}$ & $\begin{array}{l}\text { 1. Penetrasi dan pengembangan } \\
\text { pasar a tas produk-produk yang } \\
\text { sudah ada. }\end{array}$ & $\begin{array}{l}\text { 1. Meningk atkan aktivitas e- } \\
\text { commerce untuk meningka tkan } \\
\text { penjualan } \\
\text { 2. Melakukan manaj emen inventori } \\
\text { yang optimal agar se huruh stok Anda } \\
\text { selalu berada dalam kendali }\end{array}$ \\
\hline $\begin{array}{c}\text { Ancaman }(\mathrm{T}) \\
\end{array}$ & Strategi (S-T) Diversifikasi & Strategi(W-T) Difensif \\
\hline $\begin{array}{l}\text { 1. Toko Pareto (SAT, Yogya) } \\
\text { menerapkan managemen Gudang, } \\
\text { sehing ga mengurangi buffer stok tok }\end{array}$ & $\begin{array}{l}\text { 1. Membuat system terkait dengan } \\
\text { stok produk dicabang } \\
\text { 2. Menambah titik-titik distribusi }\end{array}$ & $\begin{array}{l}\text { 1. Membuat struktur organisa si yang } \\
\text { lebih baik lagi }\end{array}$ \\
\hline
\end{tabular}

Gambar 7. Matriks SWOT PT XYZ Regional III

\begin{tabular}{|c|c|c|}
\hline & Kekuatan (S) & Kelemahan $(\mathrm{W})$ \\
\hline $\begin{array}{l}\text { Matriks SWOT } \\
\text { Regiona1 VI } \\
\text { Jawa Tengah }\end{array}$ & $\begin{array}{l}\text { 1. Relationship dengan bidan yang } \\
\text { baik } \\
\text { 2. Prog ram DBA yang cukup mena rik } \\
\text { sehing ga menambah titik creating } \\
\text { demand }\end{array}$ & $\begin{array}{l}\text { 1. Problem ketersediaan produk yang } \\
\text { sering kosong di tahun } 2018 \\
\text { 2. Problem Stokiist yang behum ada } \\
\text { di se tiap cabang } \\
\text { 3. Dukung an transporta si untuk } \\
\text { meng cover ke area yang jauh masih } \\
\text { kurang dan terbatas } \\
\text { 4. Berkurangntya man power yang } \\
\text { meng cover channel GI } \\
\text { 5. Retur produk }\end{array}$ \\
\hline Pehuang $(\mathrm{O})$ & Strategi $(\mathrm{S}-\mathrm{O})$ Offensive & Strategi (W-O) Korektif \\
\hline $\begin{array}{l}\text { 6. Masih ada peluang untuk } \\
\text { pengembangan outlet Medis baik dari } \\
\text { activity maupun kerja sama } \\
\text { 7. Masih ada peluang pada markert di } \\
\text { area Non Medis yang bisa } \\
\text { dikembangkan } \\
\text { 8. Masih Banyaknya peluang Activity } \\
\text { di Medis \& Non Medis } \\
\text { (klinik, pabrik,koperasi) yang behm } \\
\text { dilakukan oleh kompetitor }\end{array}$ & $\begin{array}{l}\text { 1. Menjalin hubung an yang baik } \\
\text { kepada distributor } \\
\text { 2. Meningka tkan kompetensi SDM } \\
\text { untuk pengelolaan da ta }\end{array}$ & $\begin{array}{l}\text { 1. Mengembangkan SOP untuk } \\
\text { semua lini untuk merjamin operasional } \\
\text { aman hingg a ke customer akhir } \\
\text { 3. Meningkatkan fokus distribusi pada } \\
\text { cabang medis (mengutangi retur) }\end{array}$ \\
\hline Ancaman $(\mathrm{T})$ & Strategi (S-T) Diversifikasi & Strategi (W-T) Difensif \\
\hline $\begin{array}{l}\text { 1. Adanya Regula si Pemerintah } \\
\text { /BI/Dinkes terkait penggunaan susu } \\
\text { hamil \& menyusui di be bera pa daerah } \\
\text { yang secara teg as me larang } \\
\text { me lakukan kegiatan yang } \\
\text { berhubungan dengan promosi } \\
\text { 2. Keterbata san budget promosi }\end{array}$ & $\begin{array}{l}\text { 1. Mengeduka si konsumen dengan } \\
\text { cara bekerja sama dengan pemerinta } h \\
\text { dalam proses pemernhan kebutuhan } \\
\text { masyarakat akan produk kese hatan }\end{array}$ & $\begin{array}{l}\text { 1. Melakukan kerjasama dengan } \\
\text { pemerintah dan medis untuk } \\
\text { penye diaan produk kesehatan }\end{array}$ \\
\hline
\end{tabular}

Gambar 8. Matriks SWOT PT XYZ Regional VI

Quantitative strategic planning matrix adalah tahap pengambilan keputusan (decision stage) dan merupakan kelanjutan dari analisis SWOT. Pada analisis QSPM, masing-masing strategi alternatif diukur daya tarik relatifnya terhadap yang membuat strategi alternatif tersebut ada pada matriks SWOT. Semakin tinggi nilai total attractiveness score (TAS) yang diperoleh pada suatu strategi mengindikasikan bahwa strategi tersebut semakin menarik untuk dijalankan dan sebaliknya.
Berdasarkan perhitungan analisis QSPM pada Tabel 10, 11, 12 dan 13 diketahui peringkat kemenarikan dari masing-masing strategi alternatif yang ada pada masing-masing wilayah regional distribusi. Strategi alternatif tersebut telah diperingkatkan berdasarkan total TAS yang diperoleh. Total TAS tertinggi pertama pada matriks QSPM berada pada peringkat 1 dan seterusnya. Alternatif strategi yang menjadi prioritas strategi bagi PT XYZ pada regional I ialah meningkatkan kerapatan distribusi dengan skor 5,794. 
Regional III strategi alternatifnya adalah membuat system terkait dengan stok produk di cabang dengan skor 6,724. Hasil QSPM pada regional IV dengan skor 6,198 yaitu meningkatkan ketersediaan produk pada cabang. Pada regional VI dipilih strategi meningkatkan fokus distribusi pada cabang medis (mengurangi retur) dengan skor 9,407.

\section{Tabel 10. Hasil QSPM Regional I}

\begin{tabular}{lcc}
\hline Alternatif strategi & Total TAS & Peringkat \\
\hline Perluasan pangsa pasar & 5,183 & 3 \\
Meningkatkan kerapatan distribusi & 5,794 & 1 \\
Meningkatkan efisiensi durasi pengiriman & 5,668 & 2 \\
Meningkatkan kompetensi SDM terkait pengelolaan data & 4,809 & 7 \\
Memberikan kebijakan terbaru terkait dengan keterlambatan pembayaran (limit kredit), serta & 4,851 & 6 \\
follow up secara berkala & 5,134 & 4 \\
Menjalin hubungan yang baik kepada outlet non pareto & 5,059 & 5 \\
Mempertahankan keunggulan biaya melalui efisiensi biaya distribusi & 4,454 & 8 \\
Perancangan program Relationship Marketing & &
\end{tabular}

Tabel 11. Hasil QSPM Regional III

\begin{tabular}{lcc}
\hline Alternatif strategi & Total TAS & Peringkat \\
\hline Penetrasi dan pengembangan pasar atas produk-produk yang sudah ada. & 6,416 & 2 \\
Membuat system terkait dengan stok produk di cabang & 6,724 & 1 \\
Menambah titik-titik distribusi pada daerah perifer & 6,112 & 4 \\
Meningkatkan aktivitas e-commerce untuk meningkatkan penjualan & 6,099 & 5 \\
Melakukan manajemen inventori yang optimal agar seluruh stok Anda selalu berada dalam & 6,158 & 3 \\
kendali & 3,000 & 6 \\
Membuat struktur organisasi yang lebih baik lagi & & \\
\hline
\end{tabular}

Tabel 12. Hasil QSPM Regional IV

\begin{tabular}{lcc}
\hline Alternatif strategi & Total TAS & Peringkat \\
\hline $\begin{array}{l}\text { Membuat list outlet baru untuk dilakukan pembinaan dan branding sehingga sejalan dengan } \\
\text { demand yang sudah terbentuk }\end{array}$ & 4,870 \\
Meningkatkan kompetensi SDM yang fokus terhadap medis channel & 4,000 & 6 \\
Memastikan pelayanan penjualan dengan baik sesuai dengan permintaan pada setiap subdist & 5,207 & 3 \\
Fokus meningkatkan jumlah cabang pada GT retail Fokus pada penjualan di minimarket dan & 5,310 & 2 \\
supermarket & 6,198 & 1 \\
Meningkatkan ketersediaan produk pada cabang & 4,568 & 5 \\
Meningkatkan jumlah man power pada masing-masing cabang &
\end{tabular}

Tabel 13. Hasil QSPM Regional VI

\begin{tabular}{lcc}
\hline Alternatif strategi & Total TAS & Peringkat \\
\hline Menjalin hubungan yang baik kepada distributor & 7,336 & 4 \\
Meningkatkan kompetensi SDM untuk pengelolaan data & 8,607 & 3 \\
Mengedukasi konsumen dengan cara bekerjasama dengan pemerintah dalam proses pemenuhan & 5,172 & 6 \\
kebutuhan masyarakat akan produk kesehatan & 8,642 \\
Mengembangkan SOP untuk semua lini untuk menjamin operasional aman hingga ke customer & 2 \\
akhir & 9,407 \\
Meningkatkan fokus distribusi pada cabang medis (mengurangi retur) & 1 \\
\hline
\end{tabular}


Hasil analisis formulasi strategi memaparkan kekuatan, kelemahan, peluang dan ancaman serta strategi yang akan dilakukan perusahaan menghadapi permasalahan di PT XYZ. Masing-masing regional memiliki strategi yang berbeda dalam updaya meningkatkan volume penjualan. Dengan mengetahui kekuatan dan peluang yang ada, PT XYZ mampu menyusun program kerja ke depannya sehingga perusahaan dapat mencapai target penjualan yang telah ditetapkan.

Perusahaan harus merumuskan tujuan saluran distribusinya menurut konsumen yang ditargetkan. Strategi saluran distribusi yang baik berdampak pada pencapaian tujuan distribusi di pasar sasaran. Mengembangkan strategi pemasaran campuran, produk, harga, promosi dan tempat merupakan bentuk hubungan antara pemenuhan target pasar dan pemasaran campuran. Untuk regional I, dipilih strategi untuk meningkatkan kerapatan distribusi. Berikut ini merupakan rekomendasi program kerja yang dapat dilakukan oleh perusahaan setiap tahunnya pada wilayah distribusi regional I. Implikasi yang direkomendasikan adalah pemetaan area ruang lingkup pasar pada wilayah regional tersebut. Tujuan dari pemetaan area ini sebenarnya adalah untuk mendapatkan profil pasar, dimana dapat diketahui berapa total outlet di area tersebut, dan yang lebih penting adalah diketahuinya jumlah tiap type outlet serta letak geografis dari outlet tersebut. Dengan mapping ini maka gambaran geografis suatu daerah / area yang akan di cover bisa terdeskripsi dengan jelas, sehingga mampu mengetahui titik wilayah terpenting dalam pendistribusian produk.

Lalu untuk wilayah regional III, strategi terpilih adalah membuat sistem terkait dengan stok produk di cabang. Implikasi manajerial yang dapat diterapkan dalam strategi ini bisa diawali dengan menerapkan sistem manajemen gudang untuk mengelola pergudangan dan pendistribusian barang-barang. Tujuannya adalah agar barang yang tersimpan tetap dalam keadaan baik saat didistribusikan kepada para pelanggan atau peminta stok pada waktu dan jumlah yang tepat. Hal ini membutuhkan data yang akurat yang dapat dibantu oleh sebuah program untuk mengetahui laporan input stok masuk dan stok keluar. Sehingga didapatkan forecast yang dapat dijadikan acuan dalam menentukan persediaan barang. Sementara untuk taraf distributor, hal yang dapat dilakukan adalah memonitor service level di tiap pusat distribusi dengan menggunakan review checklist stock produk pada outlet secara berkala dan jika memungkinkan terdapat buffer stok pada outlet tersebut untuk beberapa produk yang lebih cepat terjual. Sehingga diharapkan distributor PT XYZ dapat memastikan tingkat stok yang memadai dan proses kinerja penjualan akan semakin baik.

Pada regional IV, strategi terpilih adalah meningkatkan ketersediaan produk pada cabang. Menjamin ketersediaan produk di pasar merupakan sasaran penting darisistemdistribusi.Perusahaandapatmengembangkan sistem saluran distribusi sesuai karakteristik produk dan segmen pasar yang dituju. Strategi ini dapat dilakukan dengan memperbaiki operasional distribusi yang dapat meningkatkan efektifitas dan efisiensi proses supply chain untuk meningkatkan keunggulan bersaing. Operasional distribusi akan menyingkat lead time, meningkatkan ketersediaan produk, dan penurunan biaya delivery. Salah satu upaya dalam dalam meningkatkan ketersediaan produk adalah dengan Memenuhi permintaan omni-channel. Pemenuhan pengantaran dalam transaksi order penjualan omnichannel memerlukan gudang-gudang distribusi yang mendekati dengan lokasi alamat penerima barang.

Lalu pada daerah distribusi regional VI, strategi terpilih adalah meningkatkan fokus distribusi pada cabang medis (mengurangi retur). Melihat peluang yang ada pada regional VI, dimana aktivitas medis masih memiliki banyak potensi untuk dijajaki dalam meningkatkan volume penjualan. Reputasi PT Sanghiang Perkasa atau Kalbe Nutritionals, sebagai perusahaan yang memproduksi makanan dan minuman kesehatan, tentunya akan sangat membantu sumber daya manusia yang berada pada PT Sanghiang Perkasa. Sumber daya manusia yang ada, dapat digunakan untuk mengecek saluran area distribusi yang telah ada, dan mengAnalisis area pada reginal IV, akan didapatkan profil pasar yang lengkap dengan jalur distribusi terutama untuk area medis.

\section{KESIMPULAN DAN SARAN}

\section{Kesimpulan}

Hasil analisis yang telah dilakukan terhadap seluruh aspek dalam membuat suatu formulasi strategi sesuai dengan tujuan penelitian. Berdasarkan dari hasil Analisis portofolio distribusi pada PT XYZ, jumlah saluran distribusi, peningkatan biaya promosi 
dan jumlah sumber daya manusia yang digunakan memengaruhi volume penjualan pada masing-masing wilayah distribusi. Kinerja distribusi dengan penjualan terbaik adalah daerah regional I, III, IV dan VI.

Hasil identifikasi faktor internal PT XYZ pada regional I menggunakan analisis rantai nilai menunjukkan tiga kekuatan dan lima kelemahan. Kekuatan terbesar pada regional I adalah memiliki hubungan yang baik dengan pareto outlet Sedangkan hasil identifikasi faktor eksternal peluang terbesar adalah outlet non pareto yang potensial. Untuk regional III kekuatan terbesar adalah memiliki kerapatan distribusi dan kelemahan terbesar ialah lambatnya konsolidasi internal. Untuk regional IV Kekuatan terbesar pada regional IV adalah Adanya hubungan baik dengan RS, RSB, BD, PKM, Bidan, Outlet Distribusi medis dan kelemahan terbesar ialah belum meratanya stockist nilai tertimbang. Peluang terbesar adalah masih banyak peluang bisnis di medis. Kekuatan terbesar pada regional IV adalah Program DBA yang cukup menarik sehingga menambah titik permintaan dengan dan kelemahan terbesar ialah problem ketersediaan produk yang sering kosong di tahun 2018. Peluang terbesar adalah masih Banyaknya peluang Activity di Medis dan Non Medis (klinik, pabrik, koperasi) yang belum dilakukan oleh competitor.

Berdasarkan perhitungan analisis QSPM alternatif strategi yang menjadi prioritas strategi bagi PT XYZ pada regional I ialah meningkatkan kerapatan distribusi. Untuk regional III strategi alternatifnya adalah membuat system terkait dengan stok produk di cabang. Lalu untuk hasil QSPM pada regional IV yaitu Meningkatkan ketersediaan produk pada cabang. Pada regional VI adalah strategi Meningkatkan fokus distribusi pada cabang medis (mengurangi retur).

\section{Saran}

Saat ini PT XYZ melalui PT EPMT masih berfokus pada channel offline pada masing-masing distributor. Perlu dilakukan strategi meningkatkan diferensi jasa yang dapat mendukung perluasan pasar. Terutama Pada era covid saat ini, perlu ada pengembangan pada aspek digitalisasi dan teknologi informasi. Platform digital baru untuk mendukung upaya perusahaan membangun sebuah ekosistem rantai pasok produk kesehatan berbasis digital. PT XYZ, melalui PT EPMT harus memperbanyak mitra kerja agar pendistribusiannya lebih baik dan lebih merata agar perolehan volume penjualan dapat lebih maksimal. Apabila diperlukan penambahan relasi distributor perlu dipertimbangkan oleh team marketing PT Sanghiang Perkasa. Bagi penelitian selanjutnya disarankan penelitian difokuskan pada bagian marketing. Dalam rangka meningkatkan penjualan terhadap potensi pasar pada masingmasing produk susu bubuk yang sudah ada dengan menggunakan kompetensi inti yang dimiliki oleh PT XYZ.

\section{DAFTAR PUSTAKA}

David FR. 2010. Manajemen Strategis-Konsep. Ed. ke-10. Jakarta: Salemba Empat.

Eggers JP, Chagas V. 2019. Brasil. Product and Innovation Portfolio Management. USA: Oxford research Encyclopedia of Business and Management.

Ginting A. 2006. Perumusan strategi perusahaan PT $\mathrm{X}$ menggunakan matriks evaluasi faktor. Jurnal Sistem Teknik Industri 7(1):1-5.

Gunawan S. 2005. Analisis strategi portofolio produk jasa telekomunikasi PT XYZ [tesis]. Bogor: Sekolah Program Pascasarjana, Institut Pertanian Bogor.

Hastono. 2019. Pengaruh saluran distribusi terhadap kepuasan pelanggan pada PT Frisian Flag Indonesia. Jurnal Ekonomi Kreatif 1(3): 51-63.

Hutabarat J, Martani H. 2006. Pengantar Manajemen Strategik Kontempoler Strategik di Tengah Operasional. Jakarta: Gramedia.

Iskandar DA. 2018. Strategi pengembangan portofolio bisnis PT Kawasan Berikat Nusantara (PERSERO) [tesis]. Bogor: Sekolah Program Pascasarjana, Institut Pertanian Bogor.

Keung Ho JK. 2014. An application of the systemic PEST analysis on the Internet-based sex trade sector. European Academic Research 7(2):92589273.

Mangifera L. 2015. Analisis Rantai nilai (value chain) pada produk batik tulis di Surakarta. BENEFIT Jurnal Manajemen dan Bisnis 19(1): 24-33.

Musrifah M. 2017. Pengaruh orientasi pasar dan orientasi kewirausahaan terhadap kinerja pemasaran melalui keunggulan bersaing. Management Analysis Journal 6(4):495-505.

Nurimansyah. 2011. Analisis rantai nilai (value chain) industri pakaian jadi di Indonesia [tesis]. Yogyakarta: Universitas Gadjah Mada.

Pudjadi T, Kristianto, Tommy A. 2007. Analisis untuk 
perencanaan strategi dan teknologi informasi pada PT Ritrans Cargo. Seminar Nasional Aplikasi Teknologi Informasi :1-12.

Rachadian FM. 2018. Formulasi strategi pembangkit listrik pemerintah di Jakarta [tesis]. Bogor: Sekolah Program Pascasarjana, Institut Pertanian Bogor.

Singh M. 2012. Marketing mix of 4P's for competitive advantage. IOSR Journal of Business and Management 3(6):40-45. https://doi. org/10.9790/487X-0364045

Sudarjat D. 2011. Analisis Portofolio Produk Pasar untuk Mengembangkan Perencanaan Pasar Strategis pada Perusahaan Jasa Logistik.
Jakarta: Binus Business Review.

Sulistiyantoro G. 2005. Analisis strategi portofolio produk jasa telekomunikasi PT XYZ [tesis]. Bogor: Sekolah Program Pascasarjana, Institut Pertanian Bogor.

Thompson AA, Strickland AJ, Gamble JE. 2010. Crafting and Executing Strategy: The Quest for Competitive Advantage: Concepts and Cases. Ed. ke-7. New York: McGraw-Hill.

Yuksel A, Fisun Y, Yasin B. 2009. Destination attachment: effects on customer satisfaction and cognitive, affective and conative loyalty. Tourism Management 31(2):274-284.https:// doi.org/10.1016/j.tourman.2009.03.007 